\title{
FORMA URBANA Y VIVIENDA COLECTIVA: UNA APROXIMACIÓN A LA EVALUACIÓN DE DENSIDAD
}

\author{
M. Cecilia Marengo \\ FAUD - UNC /CONICET \\ mcmarengo@unc.edu.ar
}

\section{RESUMEN}

El problema de investigación se fundamenta en la necesidad de reexaminar las formas de los tejidos residenciales, a la luz de las transformaciones derivadas de los procesos de crecimiento en las ciudades en las últimas décadas. El concepto de densidad, se presenta como una herramienta útil para proponer acciones de densificación, compactación o intensificación. Sin embargo, no es un concepto neutro, sino que fundamentalmente es relacional. Densidad y forma urbana se abordan como un binomio para analizar lo construido y reflexionar sobre las condiciones de alojamiento que permitan construir entornos urbanos vitales, con calidad residencial. La ponencia analiza conjuntos de vivienda colectiva con formas de ocupación más compactas y densas, incorporando un modelo de simulación para comparar diferentes alternativas de organización espacial disímiles en forma urbana y densidad. Atendiendo a la condición relacional del concepto, vinculamos Densidad con Calidad residencial, y aportamos conclusiones sobre criterios de densificación residencial.

Palabras Clave: Forma urbana - Vivienda colectiva- Evaluación- Densidad

\section{ABSTRACT}

The research problem is based on the need to reexamine the forms of the residential tissue, derived from the transformations on growth patterns that occurred in the cities in the last decades. The concept of density is presented as a useful tool to propose actions of densification, compaction or intensification. However, it is not a neutral concept, it is fundamentally relational. Density and urban form are approached as a binomial to analyze the urban form and reflect on housing conditions that allow achieving vital urban environments, with residential quality. The paper analyzes groups of collective housing interventions with more compact and dense forms of occupation, incorporating a simulation model to compare the different alternatives of spatial organization in terms of urban form and density. Given the relational condition of the concept, we linked Density with Residential Quality, and we conclude about residential densification criteria.

Keywords: Urban Form - Collective housing - Evaluation - Density 